\title{
THE COMPARATIVE ANALYSIS OF THE INDUSTRIAL POLICY IMPACT ON EXPORT PERFORMANCE IN THE MILITARY AND DEMOCRATIC REGIME OF PAKISTAN
}

\begin{abstract}
Amir Azam
Abstract. Since independence, the economy has always suffered from the power struggle between democracy and autocracy, which significantly damaged the economy and gave birth to different economic issues, the export sector being one of the top most affected. Once titled among Asian Tigers, the country's export overseas yields even to Bangladesh. The current study attempts to analyse the impact of industrial policy on export performance under democracy and autocracy. Many authors and past studies have argued that Pakistan lacks the long-term farsighted industrial policy. The paper considers the industrial policy instruments, import tariff, export subsidy, export rebate, R\&D expenditures, industrial expenditures and export processing zone, while export sophistication, export diversification and export competitiveness are used as indicators of export performance from 1980 till 2018. The result of the study indicates that the democracy type of a regime promotes industrialization with expanding export base and competitiveness, while the autocratic type of a regime is helpful in producing sophisticated goods. The analysis is focused on the descriptive basis by comparing the changes and growth in democracy and autocracy, while the Error Correction Model has been applied to see the adjustment of shocks and structural changes. Export sophistication and export diversification show a significant convergent effect, while export competitiveness demonstrates a divergent relation with our independent variables. The findings suggest that it is of sheer necessary to have a long-term farsighted industrial policy under conditions of stability to attract more and more investment in the economy to sophisticate, diversify and promote competitiveness.
\end{abstract}

Keywords: industrial policy, export performance, democracy regime, autocracy regime JEL Classification: C82, F13, F68, H2, H5, L16, L52

\author{
Author(s): \\ Amir Azam \\ Pakistan Institute of Development Economics (PIDE), Islamabad, 44000, Pakistan \\ E-mail: amirazam_17@pide.edu.pk \\ https://orcid.org/0000-0003-0757-7825
}

Citation: Azam, A. (2020). The Comparative Analysis of the Industrial Policy Impact on Export Performance in the Military and Democratic Regime of Pakistan. Virtual Economics, 3(2), 61-76. https://doi.org/10.34021/ve.2020.03.02(4)

Received: January 6, 2020. Revised: March 12, 2020. Accepted: April 9, 2020.

(C) Author(s) 2020. Licensed under the Creative Commons License - Attribution 4.0 International (CC BY 4.0) 


\section{Introduction}

With an inherited state of few industrial sectors, the economy, once known as Asian Tiger, is now 26th largest in terms of Purchasing Power Parity and 42nd (WITS, 2018) in terms of Nominal GDP in the world. Pakistan started its journey in 1947, with only 9 industrial units, accounting now for more than $24 \%$ share in GDP. The economy has seen some golden and worst periods in its entire journey, and a lack of long term farsighted industrial policy is one of the main issues that has remained debatable for a long time (Hayat, 1999). S. Hussain and V. Ahmed (2012) argue that the economy of Pakistan has witnessed five different waves of significant industrial policies that varied from time to time depending on the emerging shocks and structural changes because since independence Pakistan has always suffered from the struggle between democracy and autocracy. I. Hussain (2009) states that there has always been a power battle between democratic and authoritarian rulers, which made the economy suffer and put direct and indirect pressure and shifts in macroeconomic variables. Kanwal (2015) argues that it is this battle between regimes that promotes instability of the economic growth.

Since export is also one of the important factors and dimensions of the economic growth have also been affected severely, the economy has always suffered from trade deficit, except few years (Nyambane, 2013) and relied on few products that contribute the most to the total exports (Fatima \& Rehman, 2012). There is a contradiction in policy aims and objectives in authoritarian and democratic rule, which has significantly influenced the export performance. Burki (2008) maintains that the power battle between democracy and autocracy have always inversely affected the export performance because after the power change the previous policies were abolished and new policies took time to launch, and when they finally started to bring outcomes, another disturbance took place, and the economy started its journey from scratch. In Pakistan, the authoritarian government has always preferred to liberalise foreign trade, to cancel subsidies and rebates with a limited focus on R\&D expenditures and industrial investment promotion (Anjum \& Sgro, 2017), while in the opposite case, as Hayat (1999) argues, the democratic rule in Pakistan believes in restricting imports by imposing nominal tariff, providing subsidies to encourage investors to produce more efficiently and increasing R\&D expenditures to promote innovations and development, with increasing the development and industrial expenditures. So, both types of government focused only on the issues and challenges to occur without focusing on the long-term policies. Therefore, the economy unable to sophisticate and diversify is not competitive in the world market, and this made the economy suffer because Pakistan's export performance has remained unsatisfactory in last few decades (Mahmood \& Ahmed, 2017). From the WITS report (2018), Pakistan's export share in the global market have declined from $0.18 \%$ in 1990 $0.14 \%$ in 2017, while in the same period the other South Asian economies' share in the global market is increasing substantially, with India being able to increase its share from $0.61 \%$ to $1.66 \%$ and Bangladesh export share increasing from 0.06 to $0.181 \%$ in the respective period. Abbas (2015) concludes that Pakistan is focusing on extending its exports but is unable to get good shares in the world market because of too many reasons such as too narrow export base, low diversification, primary and semi-manufactured goods, 
outdated technology, technical barriers, currency devaluation and the lack of a long term farsighted industrial policy. Mahmood and Ahmed (2017) conclude that the export performance of Pakistan has the exports vulnerable to world shocks, and the constant power battle between democracy and autocracy has always encouraged this vulnerability. The industrial policy is of a paramount significance in promoting export performance. In this paper the authors try to answer the question how differently the industrial policy instruments affect the export performance under democratic and autocratic types of rule.

\section{The Literature Review}

The question of which type of a regime is good for economic growth has always been debatable. Many studies have produced different findings. Some authors (Tavares \& Wacziarg, 2001; Knutsen, 2012; Zouhaier \& Kefi, 2012; Arif et al. 2012) argue that democracy plays a significant role in improving economic growth while others (Zaouali \& Ouechtati, 2013; Shabbir, 2017; Robinson, 2006; Drury et al., 2006; Masaki \& Walle, 2014) were against democracy as, in their view, it encourages corruption, growth imbalance, nepotism which cause the economy to slow down, while autocracy is good for economic growth and development. Export is an important factor of economic growth (Saleem \& Sial, 2015), and export performance indicates the betterment of the export sector. There are many determinants of export performance such as real exchange rate, unit of the goods value, world production capability, nominal effective exchange rate, net national investment, GDP, and Gross Capital Formation (Gul \& Rehman, 2014). Sousa et al. (2008) elaborate a brief discussion on export performance determinants and indicators, in which they state that export diversification and competitiveness reveal the overall direction of export performance (Edward, 1993) and that any economy before looking towards diversification and competition looks towards export sophistication because it encourages the domestic economy to transform from low sophisticated goods to highly sophisticated.

Export sophistication explains the nature of exporting goods, how much they are sophisticated. Weldemicael (2012) says that by measuring export sophistication we can easily make the choice of the production or shift in producing goods on the basis of their sophistication. Edward (1993) maintains that newly-industrialised countries of East Asia are able to make highly sophisticated goods and make the transition to capital-intensive goods. As far as export sophistication determinants are concerned, Hausmann et al. (2007) argue that per capita income in purchasing power parity, FDI, export to GDP ratio, trade openness, human capital and share of manufacturing in total exports matter the most.

According to Khan and Saqib (1993), there is a strong correlation between industrial policy instruments and export performance indicator, and empirical results confirm the presence of cointegration among exports and output growth, export growth performance and diversification and structural change in exports for Pakistan over the period of 1973-1998. Arslan and Tatlıdil (2012) conducted a study on the determinants of export diversification around the world, which concludes that export concentration using Gini coefficient as the dependent variable with trade openness, human capital, remoteness, terms of trade, import 
of technology, domestic credit and exchange rate volatility, among which exchange rate volatility plays an insignificant role, while other variables positively influence the dependent variable. Regarding the importance of competitiveness, Kharel (2016) emphasizes that competitiveness in the manufacturing sector and export diversification play a key role. The history witnessed that those economies that were competitive with their goods on the market managed to pass the way from being underdeveloped nations to newly industrialized countries because of their long term industrial policies and strategies.

From the above studies, we can see that export performance is an important indicator of economic growth and economic development, and stability of the economy plays a major role in promoting better export performance. Industrial policy, which sometimes correlates with trade policy, plays a significant role in promoting export performance. However, there have been made few contributions in the literature concerning the relations between the industrial policy and export performance, especially comparing the relations under different regimes. The current study tries to determine this relationship using simple econometrical tools and techniques both by checking the individual relationship impact and the impact by constructing an index that will denote the industrial policy running with the determinant of dependent variables.

\section{Research Methodology}

To meet the objective set the current study follows two different approaches, i.e. descriptive statistics and econometrical tools and techniques. In descriptive statistics, we will rely on average growth and changes in the mentioned variables with graphical, diagrammatical and frequency distribution in the study period while in econometrical tools first, we will see the time series characteristic features of variables and an error correction model to find the speed of adjustment and long-term policy shocks. The econometrical specification and technique are explained below.

\subsection{Econometric Technique}

As for the presence of unit root cause spurious regression, Engle and Granger (1987) state that trended time series data could create major problems in empirical estimation due to spurious regression and the estimated values are insignificant in reality, and the problem can be resolved by taking the difference of variables until the time series get stationary and then running the regression analysis. Asteriou and Hall (2007) argue that it is also not an ideal solution to the problem of spurious regression, rather it is not only difference of the error term in the estimation, but it also gives no long-run solution. For the general equation, the following relationship can be obtained through a simple regression model.

$$
Y t=\beta 1+\beta 2 I \cdot P+\beta 3 X t+\varepsilon t
$$

where $Y t$ denotes the dependent variable that in our study are export sophistication, export diversification and export competitiveness; 
$X t$ shows determinants of the dependent variable;

I.P represents the industrial policy instruments which in the case we are taking import tariff, export subsidy, industrial expenditures, rebate, export processing zones and research and development expenditures;

$\varepsilon t$ denotes the error term.

To avoid spurious regression, we will rely on the difference of both dependent and independent variables.

$$
\Delta Y t=\beta o+\beta 1 \Delta X t+\beta 2 \Delta I . P+\varepsilon t
$$

So, from the above equation a significant conclusion can be drawn because both variables now have been transferred into difference equation and make it stationary, through which we can draw short-run relationship. But we are not only interested in a short run relationship; we are also interested in a long run relationship through which we can forecast a long-run farsighted policy. Since we pointed out that $Y t$ and $X t$ are both first-order integrated and their combination gives $I(0)$, then it means that our dependent and independent variables are co-integrated, thus in case of regression from equation 1 has now no more problem of spurious regression and now it provides us with a linear combination of dependent and independent variables.

$$
\varepsilon t=Y t-\beta 1-\beta 2 X t-\beta 3 I . P
$$

Here our error term connects dependent and independent variables in the long run.

Since $Y t, X t$ and $I . P$ showed co-integration by definition $\varepsilon t$ is stationary at level; therefore, we can introduce an Error Correction Model between dependent and independent variables.

$$
\Delta Y t=\beta 0+\beta 1 \Delta I . P+\gamma \Delta X t+\beta 3 \varepsilon t-1+\varepsilon t
$$

Equation 4 has now the advantage of both short-run and long-run information. In the given equation $\beta 1$ and $\beta 2$ shows the relationship between the dependent and independent variable in the short run while the parameter of ( $\varepsilon t-1)$ shows the adjustment among the dependent and independent variables in the long run.

Since we are interested in seeing the impact of industrial policy on export performance comparing the impact of democracy and autocracy, therefore we will use two different options to see this impact. First, we will regress the overall variables and time period in second equations and by introducing another independent variable that will treat as a dummy, i.e. "1" for autocracy and "0" for democracy. This will help us to see the entire impact on export performance. In the second option we will separate the time period regime, i.e. from 1980-1988 \& 1999-2008 showing the military regime and 1989-1998 \& 2009-2018 as a democracy, and will run two different equations and compare the 
significance of variables in each type of a regime. So, the long-run elasticity among export sophistication, export diversification and export competitiveness and industrial policy instruments are captured by $\beta^{s}, \alpha^{s}$ and $\gamma^{s}$.

\section{The Data Analysis}

\subsection{The Descriptive Analysis}

The current section analyses the descriptive features of variables in the respective regimes through graphical and diagrammatical representation of export performance and industrial policy instruments. There are many determinants of export performance, i.e. real exchange rate, a unit of the goods value, world production capability, nominal effective exchange rate, net national investment, GDP, and Gross Capital Formation (Gul \& Rehman, 2014). BeleskaSpasova (2014) elaborates a brief discussion on the determinants and indicators of export performance, in which she states that export diversification and competitiveness reveal the overall direction of export performance. So, we will use export sophistication, export diversification and export competitiveness as the determinants of export performance.

The State Bank of Pakistan shows that Pakistan's export share in the global market has declined from $18 \%$ in 1991 to $0.14 \%$ in 2017, while in the same period the export performance of competing Asian economies have shown a substantial increase, specifically the share of Bangladesh in the world exports have increased from $0.06 \%$ to $0.19 \%$, and that of India has jumped from $1.64 \%$ to $2.5 \%$ respectively in the same period. The overall exports of the economy have shown substantial growth, increasing from $\$ 3.2$ billion in 1980 to 26.8 billion in 2016 with a peak of $\$ 31.4$ billion in 2011 and $\$ 3.2$ billion in the 1980s. The average growth has amounted to $6.17 \%$ from 1980 to 2017, respectively; however, it will be a mistake to look at this growth in isolation. When we carefully analyse Pakistan's export performance in the military and democratic regimes we can see that in the period of Zia regime our export base increased from $0.15 \%$ in 1980 to $0.18 \%$ in 1990 , which in the period of democracy came down to $0.15 \%$. In Musharaf's regime our export base remained unchanged while the further democratic regime witnessed the export share fall to $0.14 \%$. The table 1 below gives a quick overview of the export share in the global market.

Table 1. The Share of Pakistan's Export in the World Exports

\begin{tabular}{cccccc}
\hline Country & 1980 & 1990 & 2000 & 2010 & 2016 \\
\hline Bangladesh & 0.04 & 0.05 & 0.09 & 0.1 & 0.19 \\
\hline India & 0.43 & 0.57 & 0.7 & 1.56 & 2.5 \\
\hline Pakistan & 0.15 & 0.18 & 0.15 & 0.15 & 0.14 \\
\hline
\end{tabular}

Source: The World Bank (2017).

Since 1980s the economy shows unstable export growth because the overall performance indicates that Pakistan's economy suffered from vulnerable export performance, which sometimes went to the negative values even when we adopted the sensitive and export 
promotion policies. Figure 1 demonstrates that there have been observed many fluctuations in export growth of the economy, and these fluctuations went even worse in the democratic regime as compared to autocracy. There are mainly three pillars of export performance showing the nature of exports, namely export sophistication, export diversification and export competitiveness. Deeply analysing the export sophistication comparing both regimes, we can see that the autocracy promotes more of the sophistication while democracy is helpful in promoting competitiveness in the global market (Abbas, 2015) and both have fluctuation experience in export diversification in terms of market and goods. The economy performed much better in the 1980 s both in terms of sophistication and diversification while 1990s promoted political instability, security threats, nepotism and barbarism and discrimination in privatisation and deregulation (Ahmad \& Hamid, 2014), which undermined the trust on the national and international markets, therefore, all three indicators of export performance, i.e. sophistication, diversification and competitiveness were badly affected. Figures 2, 3 and 4 show the growth and changes in the indicators of export performance in both autocracy and democracy. We can see that in terms of sophistication the economy saw the golden period in 2003-2006 while economy observed more diversification in 2007-2009 while becoming more competitive in the global market during 2006-2010.

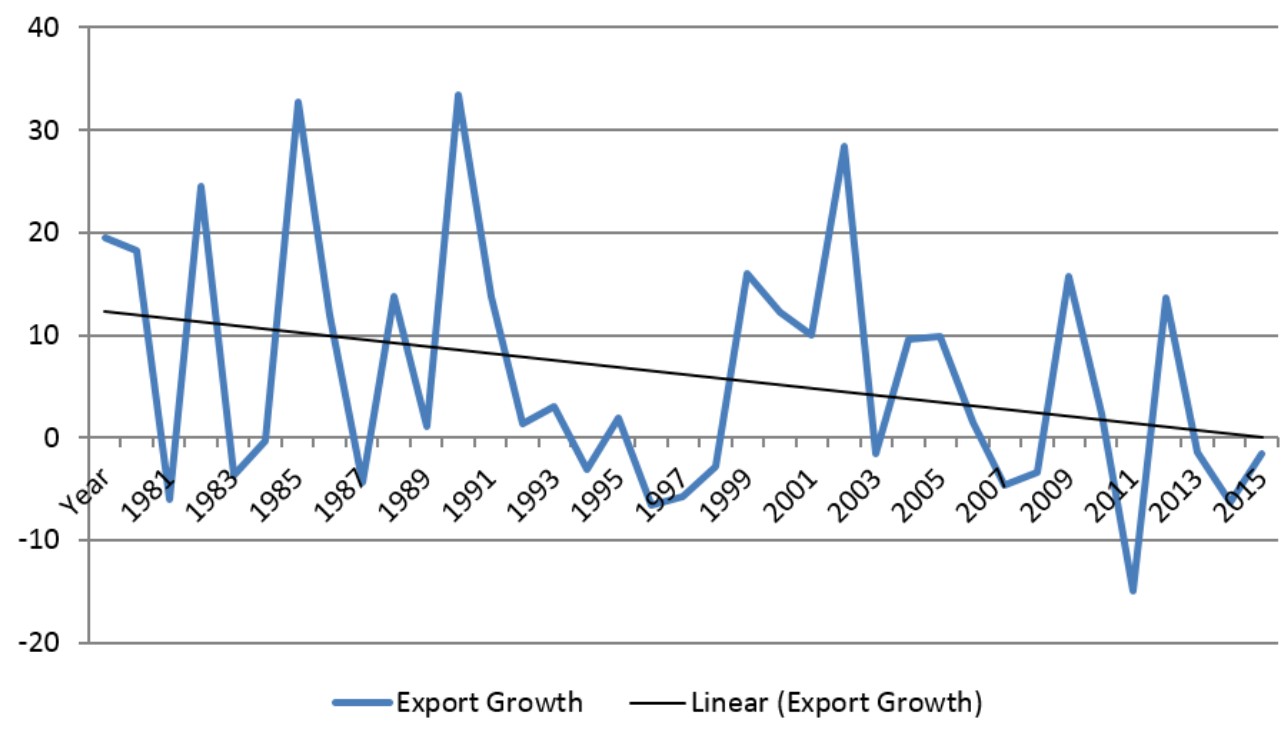

Figure 1. Pakistan's Export Growth since 1980

Source: World Integrated Trade Solution (WITS, 2018). 


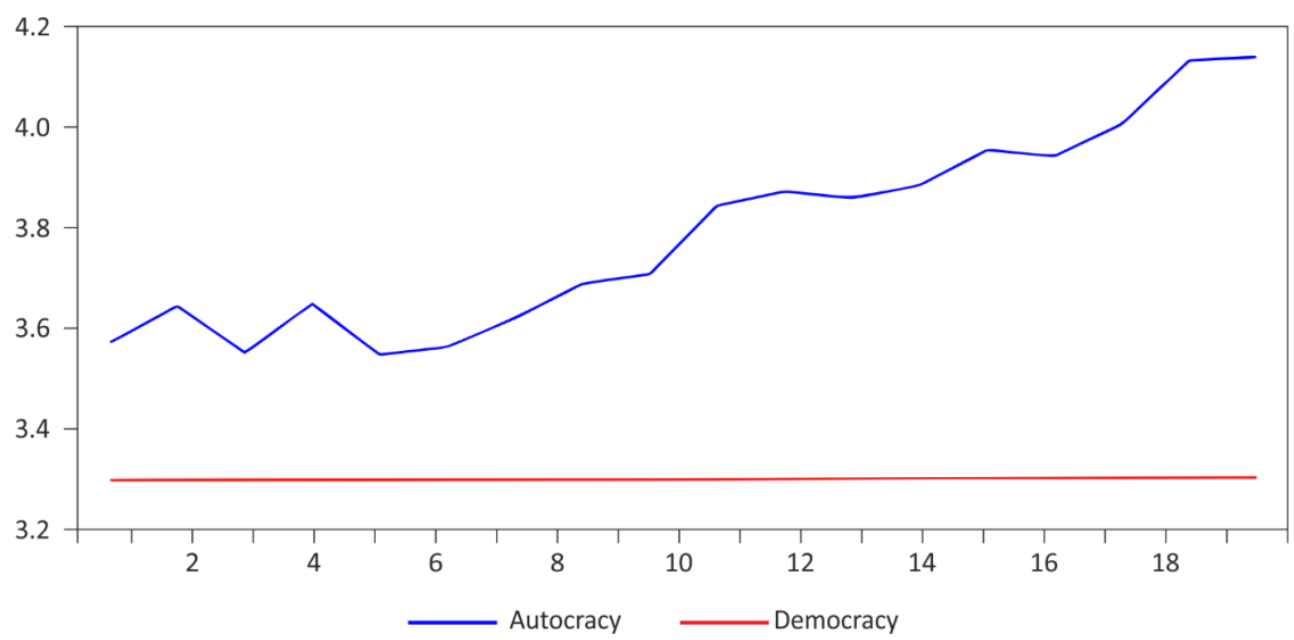

Figure 2. Pakistan's Export Sophistication

Source: World Integrated Trade Solution (WITS, 2018).

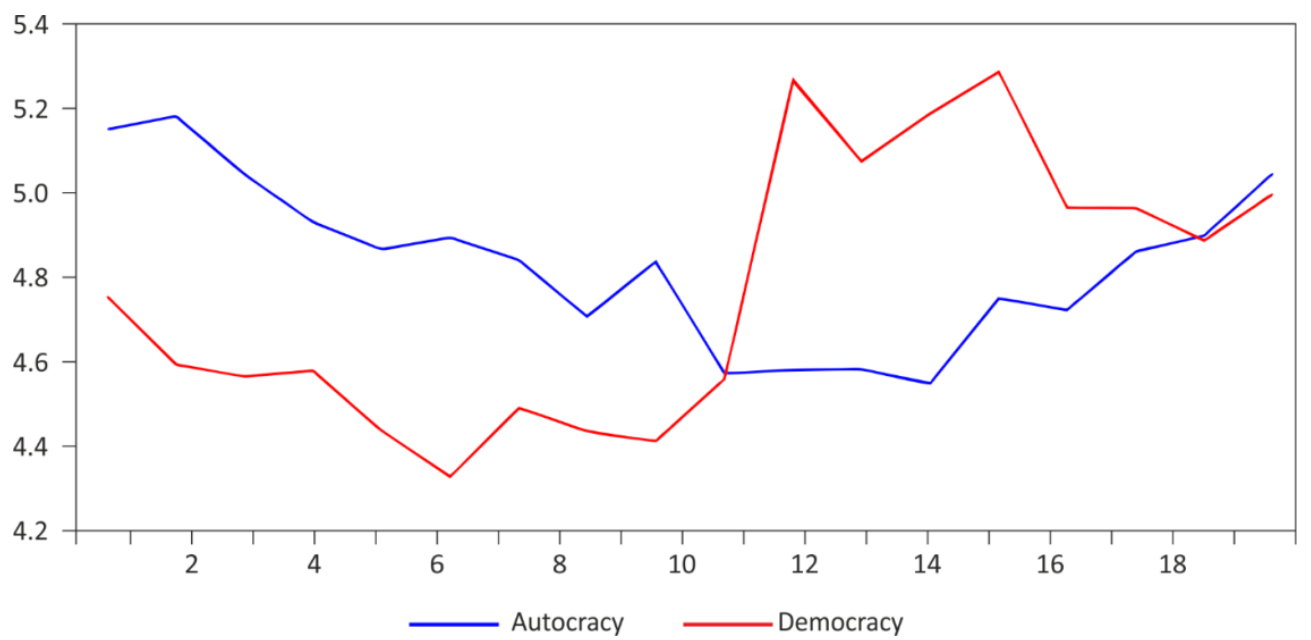

Figure 3. Pakistan's Export Diversification

Source: World Integrated Trade Solution (WITS, 2018).

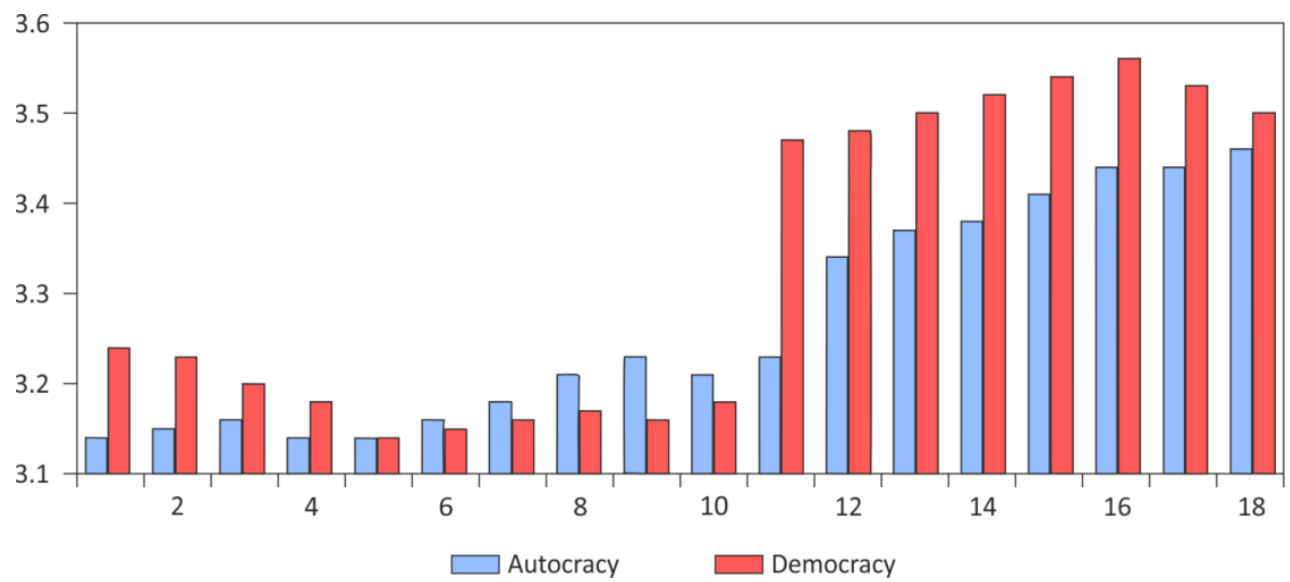

Figure 4. Export Competitiveness in Autocracy and Democracy Source: World Integrated Trade Solution (WITS, 2018). 


\subsection{Industrial Policy Instruments in Democratic and Autocratic Regimes}

Since the industrial policy is considered an important accelerator to promote the export performance, both of the regimes have their own preferences and policies. The Zia regime is known as the period of liberalisation in the Pakistani history because the Zia regime cut off the import tariff and made the economy open to international trade (Fatima \& Rehman, 2012).

On average, the import tariff was reduced from $77 \%$ in 1981 to $51 \%$ in 1988, while through denationalisation policy more than 80 nationalised industrial units were privatised under that regime. The export subsidies to exporting industries increased from $9.15 \%$ in 1980 to $10.08 \%$ in 1988 as a percentage of total subsidies. The grants increased from $0.94 \%$ to $1.99 \%$ in 1980 and 1988 respectively while the R\&D expenditures as a percentage of total national expenditures rose from $0.08 \%$ in 1980 to $0.094 \%$ in 1988 . The government passed Export Processing Zone bill in 1980 that established Pakistan's first EPZ in Karachi, which started functioning in 1994 and up to now the total export from this EPZ has been recorded at $\$ 4900$ million. After launching the Structural Adjustment Program, the economy became more open to the international market (Saleem \& Sial, 2015), but the speed of liberalisation was very low as compared to other neighbouring Asian economies because in 2000 the average import tariff rate of Pakistan, Bangladesh, Sri Lanka and India were $22.29 \%, 22.3 \%$, $8.03 \%$ and $29.13 \%$ respectively. The export subsidies have been reduced from $10.08 \%$ in 1988 to $7.27 \%$ in 1998 while the R\&D expenditures increased $0.094 \%$ to $0.115 \%$ in the respective periods. The export rebates and grants were reduced by the democratic regime of PPP and PML (N) in the period that went up from $1.99 \%$ to $1.28 \%$ in 1988 and 1999 respectively. The share of industrial expenditures went up in that regime from $19 \%$ to $21 \%$ in the respective period, which helped to promote the new industrial zones, and the EPZs of Sialkot, Risalpur and Hattar were a part of the regime that contributed and is now contributing a good share to our total exports.

In the Musharaf's regime, the government focused on encouraging FDI and privatisation. The regime of Musharraf covered the period of 1999-2007, and during this period the economy observed a very fast growth in the export sector. The exports increased from $\$ 4.13$ billion in 1999 to $\$ 14.23$ billion in 2008 . The import tariff further dropped from $14.86 \%$ in 1999 to $13 \%$ in 2008 while the export subsidies were reduced from $7 \%$ to $5 \%$ in the same period. For the first time in Pakistani history, the share of R\&D expenditures reached $0.5 \%$ share of total expenditures and government increased the share from $0.115 \%$ in 1999 to $0.6325 \%$ in 2008 , which revived the sector, and that government started to seek a new era of competitive market, while the government that followed saw the competitive market position in the international market. The second round of the democratic regime launched the industrial policy of liberalisation and privatisation focusing on diversification and competitiveness, but the sophistication sector was badly affected in the entire regime of 2008-2018. After the 18th amendment in the Pakistani constitution, the industrial policies were handed over to the provincial governments, and now the provincial governments make their industrial policies according to their natural resources, geographical location and 
infrastructure. Figures 5 and 6 give a quick overview of changes in the industrial policy instruments in the democracy and autocracy regimes.

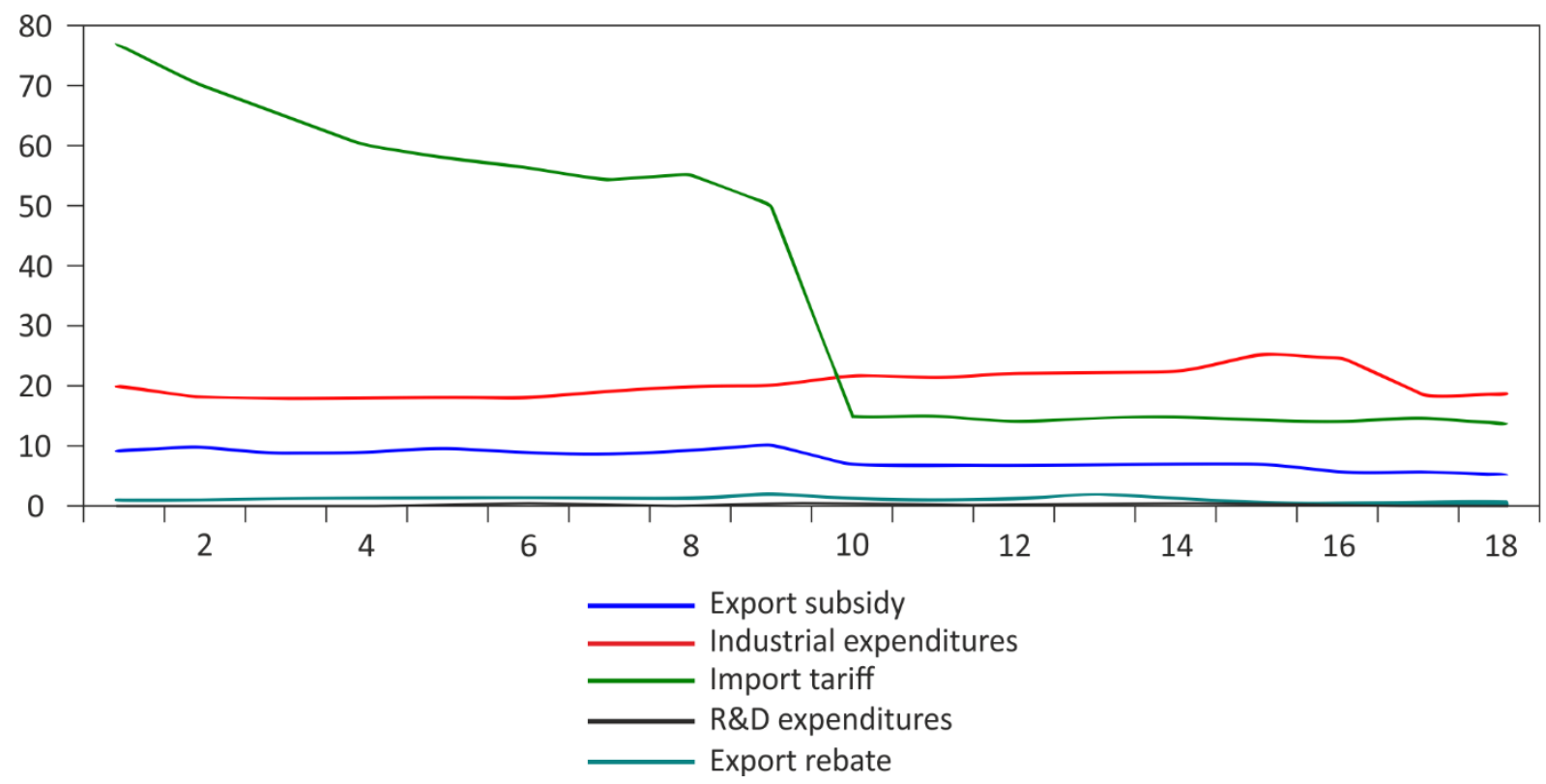

Figure 5. Industrial Policy Instruments in the Military Regime Source: World Integrated Trade Solution (WITS, 2018).

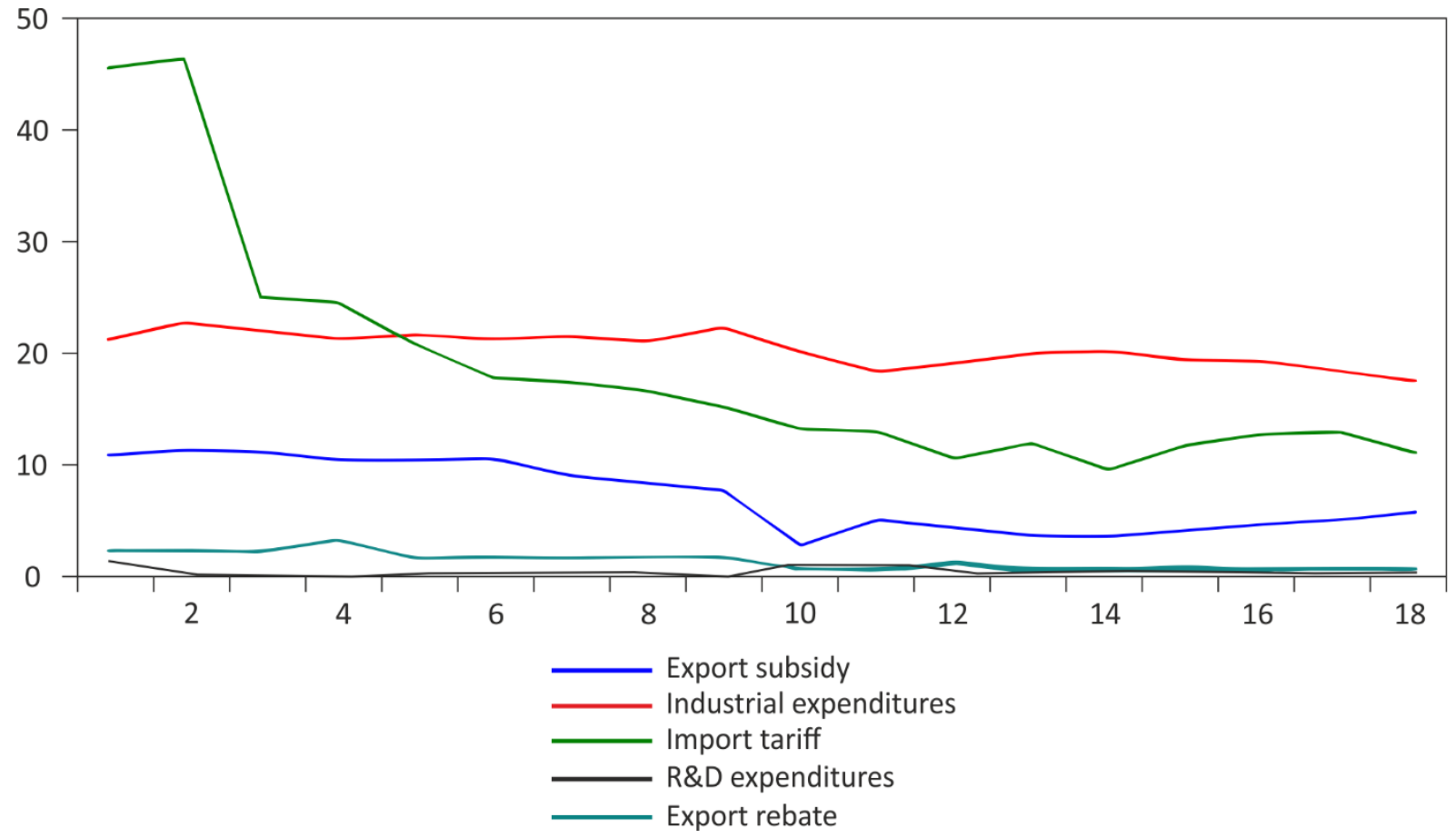

Figure 6. Industrial Policy Instruments in the Democracy Regime Source: World Integrated Trade Solution (WITS, 2018). 


\subsection{The Analysis of Industrial Policy Instruments in the Military vs Democratic Regimes in Pakistan}

Table 2 below gives econometric estimations of the coefficients of industrial policy instruments with export performance indicators differentiating the type of regimes.

Comparing the impact of industrial policy instruments on export sophistication, export diversification and export competitiveness under the military and democratic regimes, it can be seen that industrial expenditures play a significant and positive role in export diversification and export competitiveness in democratic regimes while having a positive impact in military regime only in export competitiveness, while in export diversification it has no significant role in diversifying the economy.

Table 2. The Industrial Policy Instruments' Impact on Dependent Variables under the Military vs Democratic Regimes

\begin{tabular}{|c|c|c|c|c|c|c|}
\hline \multirow[b]{2}{*}{ Variables } & \multicolumn{2}{|c|}{ Export Sophistication } & \multicolumn{2}{|c|}{ Export Diversification } & \multicolumn{2}{|c|}{ Export Competitiveness } \\
\hline & Military & Democracy & Military & Democracy & Military & Democracy \\
\hline Industrial & 0.000811 & $0.0472 * *$ & -0.0213 & 0.471 & $0.0176^{*}$ & $-0.0369 * *$ \\
\hline $\mathrm{p}$ (values) & $(-0.09)$ & (3.48) & $(-0.15)$ & $(1.46)$ & -3.03 & $(-3.05)$ \\
\hline Subsidy & 0.0251 & $-0.00320 * *$ & 0.0629 & $-1.104 * * *$ & 0.0152 & $-0.0428 * * *$ \\
\hline $\mathrm{p}$ (values) & $(-0.83)$ & $(-3.01)$ & $(-0.13)$ & $(-4.36)$ & -0.79 & $(-4.51)$ \\
\hline$R \& D$ & $0.605^{* *}$ & -0.00071 & $7.118^{*}$ & -0.0885 & $0.605^{* * *}$ & -0.0198 \\
\hline $\mathrm{p}$ (values) & $(-3.6)$ & $(-0.97)$ & $(-2.65)$ & $(-0.05)$ & -5.62 & $(-0.30)$ \\
\hline Import Tariff & $-0.085^{* *}$ & -0.0003 & $0.0850 *$ & $0.117^{*}$ & -0.00161 & $0.00429 *$ \\
\hline $\mathrm{p}$ (values) & $(-3.23)$ & $(-0.09)$ & $(-2.94)$ & $(-2.63)$ & $(-1.39)$ & $(-2.58)$ \\
\hline Rebate & -0.0347 & -0.00052 & -1.196 & 0.0823 & 0.0302 & -0.0404 \\
\hline $\mathrm{p}$ (values) & $(-0.72)$ & $(-1.39)$ & $(-1.56)$ & -0.09 & -0.98 & $(-1.21)$ \\
\hline _cons & $3.722 * * *$ & $3.314^{* * *}$ & $45.19 * * *$ & $62.52 * * *$ & $2.701 * * *$ & $4.333^{* * *}$ \\
\hline $\mathrm{p}$ (values) & $(-12.92)$ & $(-8.54)$ & $(-9.84)$ & $(-10.48)$ & $(-14.64)$ & $(-19.37)$ \\
\hline
\end{tabular}

Source: the author's own calculation.

The export subsidy plays a negative role in export sophistication, export diversification and export competitiveness. As most of the nation use export subsidy as an instrument to increase the export performance, in the case of Pakistan export subsidy has a negative impact both under the military and democratic regimes. Haq \& Kemal (2007) explain that export promotion subsidy schemes are difficult to administer and are subject to 
manipulation for rent-seeking purposes. According to our analysis of export subsidies, promoting export performance in both regimes had no significant impact on export performance, and even in democratic regimes the export subsidy shows significant negative impact, proving that increasing an export subsidy causes to reduce export performance. A careful analysis of the R\&D expenditures demonstrates that they influence export performance indicator positively and significantly in the military regimes, while in the democratic regimes, the R\&D shows insignificant positive results. The import tariff values reveal that its harmful for export performance in both regimes and will cause to reduce the export performance with a significant value of $1 \%$, while the export rebate has no significant impact on export performance in both regimes. The Wald test to remove the export rebate from the model shows it is insignificant and have no relationship with export performance, so it can be removed from the equation.

\subsection{ECM Estimations in The Autocratic and Democratic Types of a Regime}

The above calculations in 4.3 give us a comparative analysis of the relationship between industrial policy instruments and export performance indicators showing the short-run relationship. We know that industrial policy is a qualitative measure that comprises many sets of quantitative and qualitative variables describing the strength of industrial policy. Usually, policies are highly affected by internal and external shocks, structural changes, policy changes, randomness and the nature of variables. Since Independence the economy has observed many structural and policy shifts because there has always been a battle between autocracy and democracy for power control and both work on a different vision and perspective. Hence, it is important to highlight the speed of adjustment in policymaking to see what kind of adjustment is caused by the industrial policy in the long term. The table below provides a comparative analysis of the Error Correction Model to check the speed of adjustment in the long run.

From the findings of Table 3 below it becomes evident that industrial expenditures play a significant role in industrialisation in both types of a regime, where the strength of development has more features of convergence in the long run in autocracy as compared to democracy. This means that in export sophistication it takes a short-time period in autocracy to get back to the original position or initial point which has been caused by policy and structural changes or the speed of adjustment in autocracy is faster than in democracy while in the case of export diversification the speed of adjustment in the long run in democracy is quicker than in autocracy because it has both features of significant and negative convergence faster than in autocracy. A careful analysis of the adjustment speed in both types of a regime proves that in export competitiveness both regimes have similar features of convergence in the long run with almost the same speed of adjustment. The variable coefficient indicates that industrial expenditures in autocracy have no significant impact on export performance except export sophistication, while in democracy it plays a significant positive role with export performance indicators. Export subsidies and rebate showed no significant relationship with export performance, while R\&D expenditures have a significant positive impact with all indicators of export performance in both types of a regime. Import 
tariff shows the negative and significant impact in both types of a regime proving that instead of a protective measure to boost export performance we should rely on the competitive economy in a global level to boost up the export sector of the economy. The value of R2 and adjusted R2 show that the model is best fitted while AIC and SIC show the minimum values for lag length selection and the values for Durban Watson statistics suggests there is no problem of autocorrelation in the data.

Table 3. ECM Estimations in the Autocracy and Democracy Types of a Regime

\begin{tabular}{|c|c|c|c|c|c|c|c|c|c|c|c|c|}
\hline & \multicolumn{4}{|c|}{ Export Sophistication } & \multicolumn{4}{|c|}{ Export Diversification } & \multicolumn{4}{|c|}{ Export Competitiveness } \\
\hline 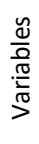 & 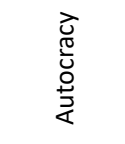 & $\frac{\bar{d}}{\frac{\pi}{2}}$ & 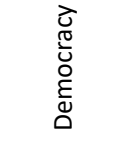 & $\frac{\frac{0}{2}}{\frac{\pi}{2}}$ & 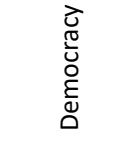 & $\frac{\bar{d}}{\frac{0}{2}}$ & 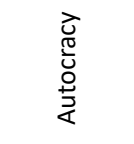 & $\frac{\frac{\partial}{2}}{\frac{\pi}{N}}$ & 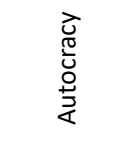 & $\frac{\bar{\partial}}{\frac{\partial}{\pi}}$ & 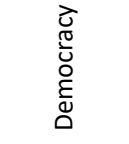 & $\frac{\frac{0}{2}}{\frac{\pi}{2}}$ \\
\hline$\underset{\varpi}{\rightleftarrows}$ & 0.00992 & $0.0714^{* * *}$ & -0.00055 & $0.0048^{*}$ & 0.8624 & 0.1099 & -0.12382 & $0.0495^{* *}$ & 0.01112 & 0.4050 & 0.03884 & $0.0241 * *$ \\
\hline$\underset{\widetilde{D}}{\widetilde{\widetilde{D}}}$ & 0.047148 & 0.1405 & $8.18 \mathrm{E}-05$ & 0.3698 & 0.324602 & 0.454 & 0.318233 & 0.4814 & 0.013876 & 0.2576 & 0.006039 & 0.554 \\
\hline $\begin{array}{l}\widehat{a} \\
\stackrel{\underline{\alpha}}{0}\end{array}$ & 0.459716 & $0.045^{* *}$ & 0.0015 & $0.0387^{* *}$ & 0.445487 & $0.0821 * * *$ & 5.442718 & $0.0554^{* *}$ & 0.423964 & $0.0087^{*}$ & 0.09759 & $0.0689 * * *$ \\
\hline$\stackrel{\overparen{a}}{\stackrel{\Xi}{o}}$ & -0.00778 & $0.0028 *$ & $-1.01 \mathrm{E}-05$ & 0.6443 & -0.046843 & 0.6477 & 0.057354 & 0.2207 & -0.00019 & 0.8734 & 0.004121 & $0.1001^{* * *}$ \\
\hline 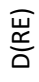 & -0.06509 & $0.0496 * *$ & -0.00021 & 0.3111 & -0.7244 & 0.4509 & -0.86936 & 0.2313 & 0.015002 & 0.4262 & -0.0104 & 0.6329 \\
\hline 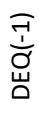 & -1.00816 & $0.0047^{*}$ & -0.00032 & $0.0232^{* *}$ & -26.9968 & $0.0906 * * *$ & -0.05627 & $0.1024^{* * *}$ & -0.6554 & $0.0472^{* *}$ & -0.58628 & $0.0044^{*}$ \\
\hline$\approx$ & 0.970212 & - & 0.87107 & - & 0.980163 & - & 0.967201 & - & 0.900073 & - & 0.896984 & - \\
\hline$\frac{\stackrel{\sim}{r}}{\frac{1}{0}}$ & 0.920308 & - & 0.86193 & - & 0.978418 & - & 0.92502 & - & 0.89075 & - & 0.85925 & - \\
\hline$\frac{\cup}{4}$ & -3.06891 & - & -12.2924 & - & 4.651985 & - & 3.262653 & - & -4.00638 & - & -2.92042 & - \\
\hline$\underline{u}$ & -2.77483 & - & -11.9983 & - & 4.946061 & - & 3.556728 & - & -3.71231 & - & -2.62634 & - \\
\hline 3 & 1.944225 & - & 1.925302 & - & 2.12455 & - & 2.023458 & - & 1.898831 & - & 1.963187 & - \\
\hline
\end{tabular}

Source: the author's own calculation. 


\section{Conclusion and Policy Recommendations}

The relationship between industrial policy and export performance has remained one of the most debatable topics in the economic history, and after the success of East Asian economies' industrial policy and instruments, it attracted more attention globally. Some economists favoured the viewpoint that a long-term farsighted industrial policy makes economy able to stand for a long-term growth depending on stability and structural changes occurring in the economy. In Pakistani developing economy, export is considered vulnerable in terms of sophistication, diversification and competitiveness. The direction and nature of exporting Pakistani goods and market are limited, usually due to little amount of market and goods while the political instability inside the territory makes it more difficult and vulnerable on the international market. Since independence, the economy has seen an almost equal periods of both autocracy and democracy. Therefore, the economy failed to adopt any long term significant industrial policy. Autocracy of the economy proved to be mostly successful in sophistication while badly affecting diversification and competitiveness. In the meantime, democracy played an insignificant role in sophistication, while in diversification it has a positive and significant role, yet having the least contribution in competitiveness.

To make the study more coherent and simpler the current study focused only on the quantitative instruments of industrial policy, i.e. industrial expenditures, export subsidy, export rebate, import tariff and R\&D expenditures. The findings of the study suggest that for industrialization autocracy has no significant impact in all cases of export performance, while democratic regime shows a significant positive impact on industrial expenditures and export performance indicators. The export subsidy and export rebate have no significant impact on export performance in both types of a regime, while import tariff shows a significant negative relationship with sophistication, diversification and competitiveness. The R\&D expenditures play a significant positive role in export performance in both regimes. Therefore, to develop a long-term farsighted policy the government needs to stabilise the political condition in the economy encouraging industrial expenditures, bringing down the export subsidies and export rebate with minimum tariff rate to make the economy open to international trade and promoting R\&D expenditures. Successful Economic Processing Zones can be used as stepping stones to boost up the export performance.

\section{References}

Abbas, A. (2015). Firm Size, Exchange Rate and Export Performance: A Firm-Level Analysis of Pakistan's Manufacturing Sector. Pakistan Journal of Commerce and Social Science (PJCSS), 9(3), 818-836.

Ahmad, H., \& Hamid, N. (2014). Patterns of Export Diversification: Evidence from Pakistan. The Lahore Journal of Economics, 19, 307-326.

Anjum, M. I., \& Sgro, M. P. (2017). A Brief History of Pakistan's Economic Development. Real-World Economics Review, 80, 171-178. 
Arif, B. W., Kayani, F. N., \& Kayani, U. N. (2012). The Interrelationship between Democracy and Economic Growth: Theories and Empirics. Pakistan Journal of Social Sciences, 32(1), 199-208.

Arslan, N., \& Tatlıdi, H. (2012). Defining and Measuring Competitiveness: A Comparative Analysis of Turkey with 11 Potential Rivals. International Journal of Basic \& Applied Sciences (IJBAS-IJENS), 12(02), 31-43.

Asteriou, D., \& Hall, S. G. (2007). Applied Econometrics: A Modern Approach. Revised Edition. Hampshire: Palgrave Macmillan, 46(2), 117-155.

Beleska-Spasova, E. (2014). Determinants and Measures of Export Performance - Comprehensive Literature Review. JCEBI, 1(1), 63-74.

Burki, S. J. (2008, September). Industrial Policy: Domestic Challenges, Global Imperatives and Pakistan's Choices. The Lahore Journal of Economics, SI, 23-34.

Drury, C., Krieckhaus, J., \& Lusztig, M. (2006). Corruption, Democracy, and Economic Growth. International Political Science Review, 27(2), 121-136.

Edward, S. (1993). Openness, Trade Liberalization and Growth in Developing Countries. Journal of Economic Literature, 31, 1358-1393.

Engle, R., \& Granger, C. (1987). Co-Integration and Error Correction: Representation, Estimation, and Testing. Econometrica, 55(2), 251-276. https://doi.org/10.2307/1913236

Fatima, G., \& Rehman, W. U. (2012). A Review of Privatisation Policies in Pakistan. Interdisciplinary Journal of Contemporary Research in Business, 3(9), 1017-1032.

Gul, S., \& Rehman, S.U. (2014). Determinants of Pakistan's Export Performance. Pakistan Business Review, 15, 544-562.

Haq, N.U., \& Kemal, M.A. (2007). The Impact of Export Subsidy on Pakistan's Export. Pakistan: Pakistan Institute of Development Economics.

Hausmann, R., Hwang, J., \& Rodrik, D. (2007). What You Export Matters. Journal of Economic Growth, $12,1-25$.

Hayat, A.M. (1999). Appraisal of Stabilization and Structural Adjustment Program in Pakistan. Journal of Economic Cooperation, 20(3), 67-84. Retrieved from https://www.sesric.org/files/article/173.pdf.

Hussain, I. (2009). The role of Politics in Pakistan's Economy. Journal of International Affairs, 63(1), 118.

Hussain, S.S., \& Ahmed, V. (2012). Experiments with Industrial Policy: The Case of Pakistan. Islamabad, Pakistan: Sustainable Development Policy Institute.

Kanwal, L. (2015). Economic Development in Pakistan: A Reflection of Social Division during 19471969. Pakistan Journal of Social Sciences (PJSS), 35(1), 497-507.

Khan, A.H., \& Saqib, N. (1993). Economic Development and International Trade. International Economic Journal, 7(3), 53-64.

Kharel, K. (2016). Assessing the Impact of Industrial Policies on Economic Development in Nepal. Economic Journal of Development Issues, 17(1-2), 40-75. https://doi.org/10.3126/ejdi.v17i12.14521 
Knutsen, C.H. (2012). Democracy and Economic Growth: A Survey of Arguments and Results. International Area Studies Review, 15, 393-415.

Mahmood, A., \& Ahmed, W. (2017). Export Performance of Pakistan: Role of Structural Factors. Pakistan: State Bank of Pakistan Working Paper.

Masaki, T., \& Walle, N. V. (2014). The Impact of Democracy on Economic Growth in Sub-Saharan Africa, 1982-2012. World Institute for Development Economics Research. https://doi.org/10.35188/UNU-WIDER/

Nyambane, E.N. (2013). Determinants of Mackahoo's Country Manufacturing Sector Competitiveness and Applicability of Porter's Diamond Model. Nairobi: School of Business, University of Nairobi.

Robinson, J.A. (2006). Economic Development and Democracy. Annual Review of Political Science, 9, 503-527. https://doi.org/10.1146/annurev.polisci.9.092704.171256

Saleem, A., \& Sial, M. H. (2015). Export Growth Nexus in Pakistan: Co-Integration and Casualty Analysis. Pakistan Economic and Social Review, 53(1), 17-46.

Shabbir, G. (2017). Corruption, Democracy and Economic Growth: Does Conditionality Matter? Pakistan Economic and Social Review, 55(1), 99-117.

Sousa, C. M.P., Martínez-López, F.J., \& Coelho, F. (2008). The Determinants of Export Performance: A Review of the Research in the Literature between 1998 and 2005. International Journal of Management Reviews, 10(4), 343-374. https://doi.org/10.1111/j.1468-2370.2008.00232.x

Tavares, J., \& Wacziarg, R. (2001). How Democracy Affects Growth? European Economic Review, 45, 1341-1378.

The World Bank. (2017). Pakistan Development Update: Growth: A Shared Responsibility. Washington, D.C., United States: The World Bank.

Weldemicael, E.O. (2012). Determinants of Export Sophistication. Retrieved from https://www.business.unsw.edu.au/About-Site/Schools-Site/EconomicsSite/Documents/E.Weldemicael\%20-\%20Determinants\%20of\%20Export\%20Sophistication.pdf

WITS. (2018). Economy of Pakistan. Washington D.C., United States of America: World Bank.

Zaouali, A., \& Ouechtati, I. (2013). Economic Vulnerability and Economic Growth: What is the Role of Institutions for MENA Countries? International Journal of Advanced Research, 1(8), 667-675.

Zouhaier, H., \& Kefi, M. K. (2012). Democracy, Investment and Economic Growth. International Journal of Economics and Financial Issues, 2(3), 233-240. 